\title{
HERPES ASSOCIATED-ERYTHEMA MULTIFORME (HAEM) IN YOUNG ADULT
}

\section{Lukman Hakim Hidayat*}

\begin{tabular}{|c|}
\hline Keywords: \\
Erythema multiforme, \\
Herpes associated \\
erythema multiforme, \\
lips lesion, HSV \\
infection
\end{tabular}

virus. Most common ages is in childhood.

Case and management: We report a case of recurrent herpes-associated erythema multiforme in a 23-year-old female patient, with crustae lesion in the lips and in pain. The patient had history of HSV infection. The patient had a fever and prodromal before the lesion emerge. And the cutaneous lesion was mistaken with the pimpleacne.

Conclusions: Although the etiology of EM is still often unknown, infections with herpes simplex virus have been implicated as common predisposing a possible precipitating factor. This case illustrates the association of the occurrence of EM with a herpes simplex virus (HSV) infection and how to managed the lesion

\section{PENDAHULUAN}

Erithema Multiformis (EM) merupakan penyakit akut yang terjadi pada mukokutaneus dengan gambaran klinis berupa erupsi polymorphous yang terdiri dari makula, papula, bula dan krusta, dapat disertai adanya lesi target di tengah lesi. Eritema multiformis termasuk dalam golongan penyakit keradangan akibat reaksi hipersensitivitas akut, dan bersifat self-limiting yang terjadi pada mukokutan, dengan etiologi yang bermacammacam ${ }^{1}$. Karakter utama EM adalah adanya lesi pada kulit, dengan atau tanpa lesi pada ronga mulut atau membran mukus yang lain. Reaksi hipersensitivitas adalah penyebab utama timbulnya EM. Namun pemicunya bisa bermacam-macam, diantaranya adalah infeksi virus Herpes Simpleks, walaupun virus herpes yang lain dapat juga menjadi pemicunya. Varisela Zoster, Cytomegalovirus dan EpsteinBarr virus juga bisa menjadi pemicu terjadinya $\mathrm{EM}^{2}$.
Obat-obatan tertentu, infeksi, kondisi imun penderita dan bahan-bahan tambahan pada makanan dapat memicu timbulnya EM. Penyakit ini, terutama timbul pada dewasa muda (20-40 tahun) dan sekitar 20\% kasus EM terjadi pada anak-anak. Lebih banyak terjadi pada perempuan daripada laki-laki, dan sekitar $70 \%$ kasus EM didahului oleh infeksi virus herpes. Pada awalnya, EM muncul sebagai gejala akut, biasanya ringan tanpa adanya gejala prodromal. Demam, limfadenopati, malaise, sakit kepala, batuk, sakit tenggorokan dan polyarthragia biasanya muncul satu minggu sebelum timbulnya eritema atau blisters ${ }^{3}$.

Eritema multiformis (EM) merupakan kondisi dengan gambaran lesi yang bermacammacam. Lesi yang muncul mempunyai gambaran makula merah irreguler, papula dan vesikula yang bergabung menjadi satu, membentuk suatu plak yang besar pada kulit. Selain itu, krusta dan blisters biasanya muncul di tengah lesi yang memberikan gambaran

*Oral Medicine Department Faculty of Dentistry Brawijaya University

Korespondensi : lukmandentist@gmail.com 
lesi target (bull's eye). Lesi oral biasanya muncul sebagai makula merah pada bibir dan mukosa bukal, nekrosis epitel, bula dan ulserasi dengan batas ireguler, serta biasanya terlihat adanya inflammatory halo. Salah satu pemicu terjadinya EM adalah infeksi virus, terutama virus herpes simpleks (HSV), dan disebut sebagai Herpes Associated Erythema Multiforme (HAEM) ${ }^{4,5}$.

Autoreactive T-cells yang dipicu oleh infeksi virus memainkan peran penting dalam patogenesis HAEM. Virus herpes simpleks (HSV), baik HSV 1 dan HSV2 dapat memicu timbulnya HAEM. Sebanyak 66,7\% kasus lesi kutan pada HAEM terdapat infeksi HSV 1, 27,8\% terdapat infeksi HSV 2 dan infeksi keduanya pada $5,6 \%$ kasus HAEM. Herpes associated erythema multiforme (HAEM) merupakan penyakit kambuhan (rekuren), dapat dipicu oleh paparan sinar matahari dan tidak bisa meningkat menjadi steven-johnson syndrome ${ }^{6}$. Secara klinis, lesi virus HSV muncul 2-17 hari mendahului lesi target pada HAEM. Gejala prodromal nonspesifik seperti headache,malaise dan demam mendahului lesi pada HAEM. Lesinya dapat persisten, cyclical (acute dan self-limiting) dan rekuren. Lesi yang rekuren dan cyclical terutama terjadi pada HAEM. Bibir merupakan tempat utama munculnya lesi dari infeksi HSV pada HAEM. Diagnosis HAEM ditegakkan secara klinis dan lebih mudah dikenali apabila ada lesi target yang didahului oleh lesi dari infeksi HSV. Lesi yang khas pada kutan dan mukosa atau keduanya, mendukung diagnosis klinis HAEM. Pemeriksaan serologi untuk mengidentifikasi HSV-1 dan HSV-2 serta untuk mendeteksi adanya antibodi spesifik lgM dan lgG dapat dijadikan pemeriksaan penunjang diagnosis HAEM ${ }^{7}$.

Pemicu eksogenus terutama dapat menyebabkan reaksi imunologis yang bermanifestasi adanya vesikula intraepitel. Diagnosis HAEM ditegakkan secara klinis dan lebih mudah dikenali apabila ada lesi target yang didahului oleh lesi dari infeksi HSV. Lesi yang khas pada kutan dan mukosa atau keduanya, mendukung diagnosis klinis HAEM. Pemeriksaan serologi untuk mengidentifikasi HSV-1 dan HSV-2 serta untuk mendeteksi adanya antibodi spesifik $\lg M$ dan $\lg G$ dapat dijadikan pemeriksaan penunjang diagnosis HAEM ${ }^{8,9}$.

\section{KASUS}

Seorang perempuan berusia 23 tahun, mahasiswi datang ke klinik Rumah Sakit Universitas Brawijaya dengan keluhan bibir melepuh dan terasa sakit sejak 3 hari sebelumnya. Keluhan muncul tiba-tiba dan terasa sakit hingga tidak bisa makan dan mengganggu aktivitas bicara. Sebelum luka dan sariawan di bibir timbul, pasien merasa demam dan sakit tenggorokan serta badan terasa lemas. Keluhan berlangsung beberapa hari sebelum timbul luka di bibir. Sudah diobati oleh dokter umum namun belum sembuh. Pasien sudah menggunakan obat oles steroid untuk mengobati lukanya.

Menurut anamnesis, adik pasien juga sedang mengalami demam dan cacar. Pasien memiliki riwayat asma yang didapat dari ayahnya yang juga menderita asma dan alergi seafood. Secara klinis terlihat krusta kuning kemerahan, ulserasi, erosi pada bibir bawah dan vesicle pada pipi kiri (lih. Gamb. 1).

Berdasarkan anamnesis dan gambaran klinis pasien di diagnosis sementara sebagai HAEM, dan di diagnosis banding dengan actinic cheilitis. Pada kunjungan I dilakukan rujukan untuk pemeriksaan darah lengkap dan 

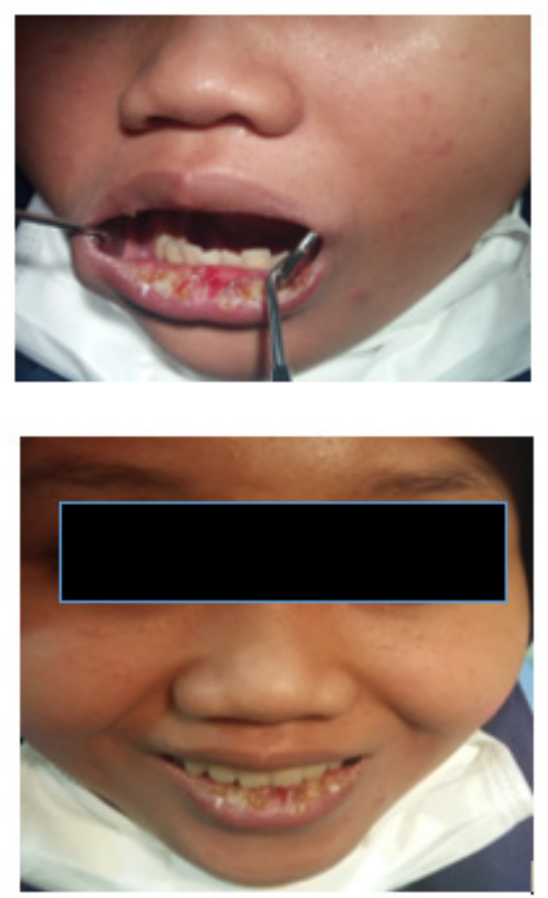

Gambar 1. Gambaran klinis kunjungan I

serologi Ig spesifik virus HSV. Dan diberikan obat parasetamol 500mg, acyclovir $400 \mathrm{mg}$, imunomodulator, obat topikal racikan dengan komposisi kortikosteroid, antibiotik, vaselin dan basis gel. Instruksi bed rest dan menghindari kontak dengan anggota keluarga.

Pada kunjungan kedua ( hari ke-7), secara klinis keluhan sudah berkurang dan pasien mengkonsumsi obat sesuai anjuran. Edukasi meningkatkan diet suportif dan bed rest dilakukan oleh pasien. Hasil pemeriksaan darah lengkap menunjukkan nilai normal, sedangkan hasil pemeriksaan imunologi Ig spesifik, menunjukkan nilai positif untuk IgG spesifik HSV-1 dengan nilai $41,2 \mathrm{U} / \mathrm{mL}$ dengan batas nilai negatif kurang dari $20 \mathrm{U} /$ $\mathrm{mL}$. Berdasarkan pemeriksaan penunjang diagnosis definitif pasien adalah HAEM dan diinstruksikan untuk melanjutkan pengobatan dengan obat topikal racikan.

Pada kunjungan ketiga (hari ke-14), keluhan pasien sudah sembuh dan bisa beraktivitas normal kembali. Obat dikonsumsi sesuai dosis
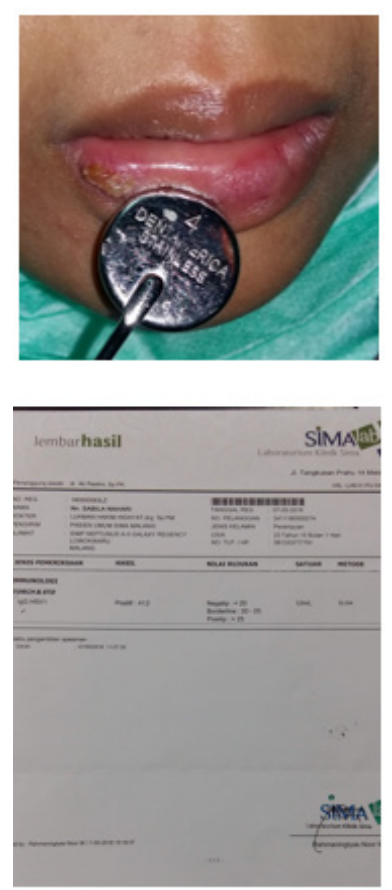

Gambar 2. Gambaran klinis kunjungan II dan hasil pemeriksaan imunologi

dan menjalankan anjuran. Pasien dinyatakan sembuh dan perawatan selesai. Secara klinis dapat dilihat pada gambar di bawah ini:

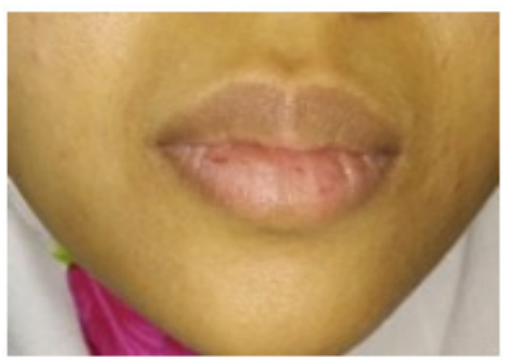

Gambar 3. gambaran klinis kunjungan III

\section{DISKUSI}

Herpes-associated Erythema Multiforme (HAEM) pada kasus ini merupakan HAEM minor yang hanya terbatas pada bibir dan mukosa oral saja. Patogenesis HAEM masih menjadi perdebatan dan beberapa literatur menyebutkan bahwa etiopatogenesis HAEM masih belum jelas hingga sekarang. Namun beberapa teori mengenai etiopatogenesis HAEM juga berkembang. Patogenesis HAEM 
termasuk ke dalam reaksi hipersensitivitas tipe 4 atau disebut juga sebagai delayed-type hypersensitivity ${ }^{10}$.

Dimulai dari perpindahan (transport) fragmen DNA virus HSV ke bagian tubuh tertentu (bibir) melalui peredaran darah perifer dengan sel-sel mononuklear. Fragmen DNA virus tersebut kemudian diekspresikan di keratinosit yang berakibat adanya pergerakan (recruitment) sel-sel HSV-spesific CD4+ Th 1 yang termasuk dalam sistem imun seluler. Sel CD4+ tersebut kemudian memberikan respon terhadap antigen virus HSV dengan memproduksi sitokin interferon gamma (IFN-Y) yang kemudian memulai kaskade inflamasi dan menyebabkan kerusakan jaringan ${ }^{11}$.

Pengobatan pada HAEM tergantung dari keparahan dari gambaran klinis yang muncul. Pada kasus ini, merupakan tergolong kasus HAEM yang ringan, pada umumnya dapat sembuh dalam 2 minggu. Beberapa ahli menyebutkan, pada kasus EM yang ringan tidak diperlukan adanya pengobatan. Pemberian anti nyeri, perawatan pada lesi bibir, dan pemberian imunomudulator serta diet makanan (terutama makanan cair) dengan gizi seimbang memainkan peran penting pada kasus ini. Pemberian parasetamol bertujuan sebagai relief of pain ${ }^{12}$.

Pemberian acyclovir merupakan pengobatan utama pada HAEM. Acyclovir, selain sebagai anti virus, juga berperan dalam mempercepat penyembuhan lesi. Selain itu, imunomudulator diberikan untuk meningkatkan kekebalan tubuh terhadap penyakit dengan cara merangsang produksi sel $\mathrm{T}$ (limfosit T), meningkatkan fungsi T-killer cell, mendukung fungsi sel NK (Natural Killer), peningkatan aktivitas limfosit $\mathrm{B}$ dan peningkatan produksi imunoglobulin, serta intensifikasi aktivitas fagositik. Jadi, respons imun tubuh yang meningkat adalah sistem imunitas seluler dan humoral. Selain itu, imunomudulator juga sebagai suplemen untuk meningkatkan nafsu makan sehingga membantu meningkatkan asupan makanan sebagai terapi suportif untuk HAEM ${ }^{6,13}$.

Diagnosis dan pemeriksaan klinis yang tepat merupakan kunci utama pengobatan HAEM, penanganan yang cepat mempunyai peran yang penting dalam tatalaksana HAEM. Pemeriksaan penunjang laboratorium juga penting dalam penegakkan diagnosis, pada kasus ini, hasil pemeriksaan immunologis menunjukkan IgG spesifik HSV-1 positif. Sehingga diagnosis definitif HAEM dapat ditegakkan. Pengenalan dan eliminasi faktor etiologi merupakan faktor penting dalam pengobatan HAEM. Informasi dan pemeriksaan terhadap riwayat alergi, pemakaian obat dan infeksi virus merupakan faktor-faktor yang harus dikenali dalam pengobatan HAEM. Terapi suportif, pemberian antivirus pada awal fase timbul lesi dan relief of pain adalah pengobatan utama HAEM ${ }^{2,3,14}$.

\section{DAFTAR PUSTAKA}

1. Kishore, Sunil R Panat, Ashish Aggarwal, Nitin Upadhyay NA. Herpes Associated Erythema Multiforme-A Diagnostic Dilemma Mallika. 2009;01(02). Available from: http://www. billbabin. com/can-karate-turn-back-the-clock

2. Chen Y-C, Chang C-H. Herpes Simplex Virus -Associated Recurrent Erythema Multiforme: The Implication of MHC Class Molecules on Susceptibility. Dermatol Sin. 2008;165-70.

3. Issrani R. Etiopathogenesis of Erythema Multiforme - A Concise Review. Adv Dent Oral Heal [Internet]. 2017;5(4). Available from: http://www.juniperpublishers.com/adoh/ADOH. MS.ID.555669.php

4. Kamala KA, Ashok L, Annigeri RG. Herpes associated erythema multiforme. Contemp Clin Dent [Internet]. 2011;2(4):372-5. Available from: https://www.ncbi.nlm.nih.gov/pubmed/22346171

5. Weston william L. Herpes-Associated Erythema Multiforme. J Invest Dermatol. 2005; 
6. Z. S, M. M, A. E. Erythema Multiforme Associated with Misoprostol: A Case Report. Am J Ther. 2016;23(5):2-5.

7. Aurelian L, Ono F, Burnett J. Herpes simplex virus (HSV)-associated erythema multiforme (HAEM): $A$ viral disease with an autoimmune component. Vol. 9, Dermatology online journal. 2003. 1 p.

8. Farthing P, Bagan J, Scully C. Can China Counter A Global Recession. 2005;44(Iv):261-7.

9. Léauté-Labrèze $C$, Lamireau $T$, Chawki $D$, Maleville J, Taïeb A. Diagnosis, classification, and management of erythema multiforme and Stevens-Johnson syndrome. Arch Dis Child [Internet]. 2000 Oct;83(4):347-52. Available from: https://www.ncbi.nlm.nih.gov/pubmed/10999875

10. Gürkan A, Sarikaya E, Demirkesen C, Yilmaz G, Midilli K. The Overlap of Fixed Drug Eruption and Human Herpes Virus Type II Associated Erythema Multiforme. 2018.

11. Sen P, Chua SH. A case of recurrent erythema multiforme and its therapeutic complications. Ann Acad Med Singapore. 2004;33(6):793-6.

12. Osterne RLV, Matos Brito RG de, Pacheco IA, Alves APNN, Sousa FB. Management of erythema multiforme associated with recurrent herpes infection: a case report. J Can Dent Assoc. 2009;75(8):597-601.

13. Blyta Y, AK, M F, A G, NA. Multiforme Erythema, In Child, After Repeated Herpes Simplex Infections - Case Presentation. J Clin Exp Dermatology [Internet]. 2011;02(05). Available from: https:// www.omicsonline.org/multiforme-erythema-inchild-after-repeated-herpes-simplex-infectionscase-presentation-2155-9554.1000127. php?aid=1863

14. Koopaie M. Burket's Oral Medicine: 12 th ed 2015 (in persian - vol 1). 2018. 